\section{Novel Palm OIL Based Polyols With amine FUNCTIONALITY SYNTHESIS VIA RING OPENING REACTION OF EPOXIDIZED PALM OIL}

\author{
Sabrina Soloja*, Rohah Abd Majidb, Abdul Razak Rahmatb \\ aFaculty of Science and Natural Resource, Chemistry Department \\ UMS, 88400, Kota Kinabalu, Sabah, Malaysia
}

bFaculty of Chemical and Energy Engineering, Polymer Department, Universiti Teknologi Malaysia, 81310 UTM Johor Bahru, Johor, Malaysia
Article history

Received

16 May 2017

Received in revised form

21 May 2018

Accepted

15 June 2018

Published online

5 October 2018

\section{*Corresponding author} sabrinas@ums.edu.my

\section{Graphical abstract}

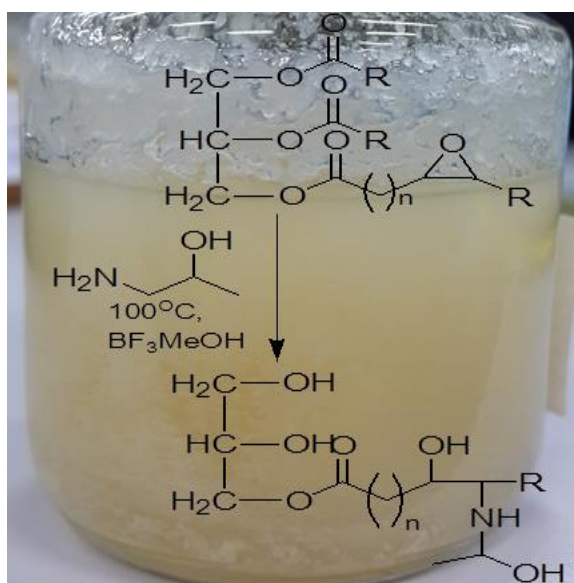

\begin{abstract}
In polymer chemistry, polyol usually used as starting materials for polyurethane (PU) production in which upon reacted with isocyanate will affect the physical and chemical properties of the obtained PU. Polyols that are mostly derived from petrochemical resources are facing issues such as depletion of petroleum sources as well as the increasing in market price. Ring opening reaction (ROR) of epoxidized palm oil (EPO) had been carried out using isopropanolamine (IPA) to impart polyol with amine functionality. The effect of reaction time on the opening of oxirane ring was investigated. FTIR spectra showed that the oxirane ring opening of EPO can occur at 6 hours reaction time, corresponding to the deacreasing intensity of oxirane $\mathrm{COO}$ twin band at $824-830 \mathrm{~cm}^{-1}$. The $\mathrm{OH}$ value of the aminefunctionalized-polyol was calculated at around $240-253 \mathrm{mg} \mathrm{KOH} / \mathrm{g}$. By prolonging the reaction time the $\mathrm{OH}$ value has slightly reduced. Mass spectroscopy analysis revealed that the polyol has a molecular weight in the range of oligo-polyols (400 $500 \mathrm{Da})$.
\end{abstract}

Keywords: Ring opening reaction, epoxidized palm oil, isopropanolamine, bio-base polyols

\begin{abstract}
Abstrak
Poliol biasanya digunakan dalam industri penghasilan poliuretan (PU) di mana, apabila ia bertindak balas dengan komponen isosianat akan mempengaruhi sifat fizikal dan sifat kimia PU yang terhasil. Poliol yang biasanya didapati di industri adalah dihasilkan daripada sumber petroleum dan kini mengalamai kekurangan sumber serta peningkatan harga pasaran. Tindak balas pemutusan rantai gelang epoksida minyak kelapa sawit (EPO) telah dijalankan dengan menggunakan isopropanolamine (IPA) sebgai agen pembuka gelang untuk menghasilkan poliol berasaskan sumber alam yang mempunyai kumpulan berfungsi amine. Pengurangan keamatan puncak kumpulan epoksida pada bacaan $824-830 \mathrm{~cm}^{-1}$ pada spektrum FTIR menunjukkan bahawa pemutusan gelang epoksida boleh berlaku selepas tindak balas dilakukan selama 6 jam. Nilai $\mathrm{OH}(\mathrm{OH}$ Value) poliol yang terhasil didapati berada pada julat $240-253 \mathrm{mg} \mathrm{KOH} / \mathrm{g}$ dan apabila masa tindak balas dipanjangkan sehingga 24 jam, didapati nilai $\mathrm{OH}$ menurun sedikit. Spektroskopi jisim (MS) menunjukkan bahawa poliol yang dihasilkan mempunyai berat molekul dalam julat oligo-poliol yakni 400-500 Da.

Kata kunci: Tindak balas pembukaan gelang, minyak kelapa sawit terepoksida, ispropanolamine, poliol sumber alam.
\end{abstract}




\subsection{INTRODUCTION}

The awareness to produce eco-friendly materials for environmental sustainability has triggered extensive studies to use renewable resources such as the use of plant oils as raw materials in many polymer syntheses [1]-[3]. Soybean oil, castor oil, sunflower oil, palm oil, rapeseed oil, olive oil, linseed oil and so on, with a worldwide production increasing continuously in 10 years (especially soybean and palm oil), (Figure 1) are used mainly in various of application including food and non-food applications. For instance, polyols derived from soybean oil [4]-[6], canola oil [7] or jatropha oil [8] have been used to react with diisocyanates to produce polyurethane. The abilities of these plant oils to be transformed into polyols are due to the existence of some reactive functionality/unsaturated sites such as ester, double bond or triple bond in their molecular structures [2], [3], [9], [10]. Some oils have natural built-in functional groups such as hydroxyl (castor oil), epoxide (vernonia oil) or ketone (licania oil) [11]. Ester and double bond have been subjected to many chemical reactions to introduce hydroxyl functionality $(-\mathrm{OH})$ including transamidation [12], esterification [13], hydroformylation [14], Ozonolysis [15], and epoxidation [3]. Among them, epoxidation gives wide possibilities for chemical transformation due to the high reactivity of oxirane ring to undergo nucleophilic attack by ring opening reagent to produce a variety of products such as alcohols, glycols, alkanolamines, carbonyl compounds and polymers [16].

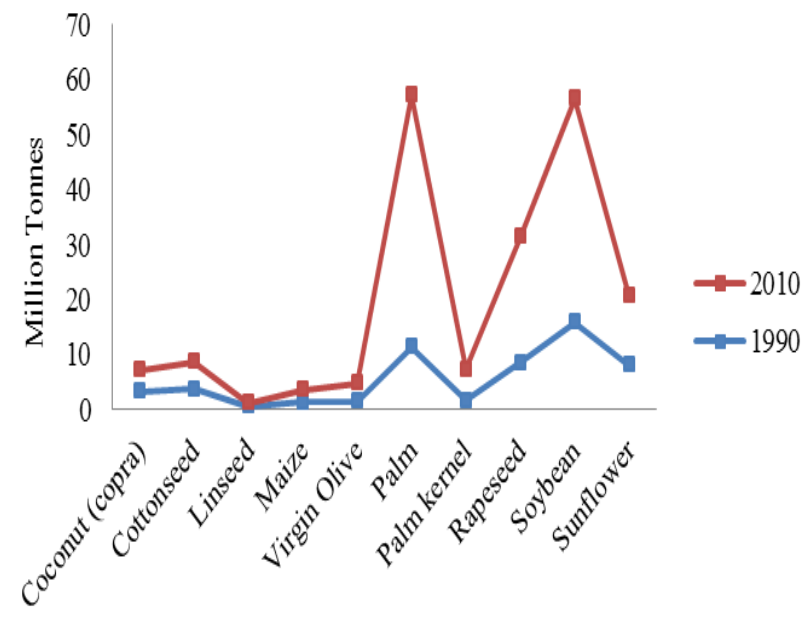

Figure 1 World production of some vegetable oils in 1990 and 2010 [17]

In Malaysia, palm oil has a yield capacity of about 4-6 tons of oil per hectare per year for the best commercial plantation [18]. Due to the increasing awareness of the social community towards environmentally friendly products, it is desirable to study the ability of palm oil to replace for petroleum based polyols. A local available palm oil has undergone some extensive studies to convert the oil into palm oil-based polyols (PO-p) via few reaction routes such as epoxidation [19], transamidation [20] and transesterification [21]. The second and the third reaction routes usually require high reaction temperature up to $200^{\circ} \mathrm{C}$ [22] and give high yields. Both routes involve the reaction with the ester linkage without disturbing the carbon double bond $(-\mathrm{C}=\mathrm{C}-)$ of the oil. Therefore, the further reaction is needed to cure the $-\mathrm{C}=\mathrm{C}$ - site because the presence of $\pi$ bonds of $-\mathrm{C}=\mathrm{C}$ - may lower the melting point of the final product, thus affecting its thermal stability [23]. On the other hand, epoxidation reaction needs lower temperature ranges of $40^{\circ} \mathrm{C}$ to $60^{\circ} \mathrm{C}$ to give ca. $95 \%$ conversion [24] and the reaction occurs directly at the $-\mathrm{C}=\mathrm{C}$ - reactive site. The epoxidized palm oil (EPO) is an important intermediate for polyurethane industry where EPO undergoes ring opening nucleophilic reaction to form polyol. Ring opening reagents such as alcohol, water, acid and amine [1] have been used to produce various types of polyols. These reagents are crucial in determining the hydroxyl value $(\mathrm{OHV})$ of the respective polyols. For example, if acid and alcohol are used, the $\mathrm{OH}$ value is $300 \mathrm{mg} \mathrm{KOH} / \mathrm{g}$ [25], and if amine was used, the OHV will be higher [26]. In addition, the reagents used will affect the synthesis step in ring opening reaction (ROR). For example, multi preparation step with an excess of solvent and molar ratio are needed for ROR with alcohol and acid reagents [27]. Recently, Miao [28] have used amino alcohol-based reagent, which is isopropanolamine (IPA) to be reacted with epoxidized soybean oil (ESO). The synthesis was conducted at low temperatures of $80-$ $100^{\circ} \mathrm{C}$ using one-pot synthesis technique with a mild condition, less solvent and produce polyols with $\mathrm{OHV}$ around $310 \mathrm{mg} / \mathrm{KOH}$.

This study has adopted the same reagent by reacting IPA with EPO at different reaction time with Lewis acid to catalyze the reaction due to weak nucleophile character of IPA compared with alcohol or amine alone [29]. Lewis acids such as stearic acid [29], tetrafluoroboric acid [30], and p-tolvenesulfonic acid [31] were well known to assist the ring opening reaction. However, these acids work well at high temperature i.e. $150^{\circ} \mathrm{C}$ [31]. Due to this reason, boron trifluoride-methanol-complex ( $\left.\mathrm{BF}_{3}-\mathrm{MeOH}\right)$ was used in this study since it has the ability to catalyze the reaction at moderate temperature, stable, less toxic and promotes similar manner in reaction pathways like hydrochloric acid $(\mathrm{HCl})$ and sulphuric acid $\left(\mathrm{H}_{2} \mathrm{SO}_{4}\right)$ [32], [33]. The main objective of this study was to investigate the availability of the IPA to open the epoxy ring of the EPO. It is important to state that the palm oil polyols obtained here will be used for polyurethane synthesis that will be reported in another publication. 


\subsection{METHODOLOGY}

Epoxidized Palm Oil (EPO) was supplied by Budi Oil Sdn Bhd (specification: $O O C=2.7-2.9 \%, M_{w}=848.75$ Da, moisture content $=0.3 \%$ ), Isopropanolamine (IPA) as ring opening reagent was purchased from SigmaAldrich, acid catalyst boron trifluoride-methanolcomplex $\left(\mathrm{BF}_{3}-\mathrm{MeOH}\right)$ was purchased from MerckSchuchardt and chloroform (AR Grade) as quenching agent was obtained from Friendmann Schmidt. All chemicals were used as received.

\subsection{Ring Opening Reaction}

The pre-set amount of EPO and isopropanolamine were charged into $250 \mathrm{ml}$ reaction flask. The molar ratio of EPO to the amino group for this study was fixed at 1:3. The reaction mixture was stirred at $70^{\circ} \mathrm{C}$ for 30 minutes under nitrogen flow. Then, $1 \mathrm{ml}$ of $\mathrm{BF}_{3}$ $\mathrm{MeOH}$ acid was added dropwise and continuously stirred until finished. Afterward, the reaction temperature was increased to $100^{\circ} \mathrm{C}$ and the mixture was continuously stirred for 6 hours. Once completed, the reaction was quenched with $100 \mathrm{ml}$ of chloroform in order to deactivate any unreacted reagent. The unreacted IPA, EPO, as well as the catalyst, were then washed with copious amount of distilled water in a separating funnel. The organic phase which contains the product was collected and further purified with a rotary evaporator to remove the solvent. The purified polyols existing as a yellowish waxy like semi-solid compound at room temperature was then ready for characterization. This procedure was repeated at different reaction times namely, 6, 12, 18 and 24 hours and the polyols obtained were coded as PRT6, PRT12, PRT18, and PRT24 respectively.

\subsection{Fourier Transform Infra-Red (FTIR)}

Attenuated Total Reflectance (ATR) FTIR was used to investigate the changes in functional groups of the EPO after ROR was done. Sample measurement was conducted by directly applied the sample on top of the sample detector and was scanned 40 times under wavelength in the range of $4000 \mathrm{~cm}^{-1}$ to 400 $\mathrm{cm}^{-1}$. The sample was processed using Shimadzu IRTracer 100

\subsection{Nuclear Megnetic Resonance Spectroscopy (NMR)}

'H NMR (proton NMR) was used to determine the number and type of hydrogen atoms in the molecule. The sample was run using NMR Bruker $400 \mathrm{MHz}$ with $5 \mathrm{~mm}$ dual probe. For each formulation, $5 \mathrm{mg}$ of sample was dissolved with $3 \mathrm{ml}$ chloroform-D $\left(\mathrm{CDCl}_{3}\right)$ in the NMR tube before placing it in the sample holder for scanning. The spectra of the sample were processed using TopSpin NMR software.

\subsection{MALDI-TOF Mass Spectroscopy}

The molecular weight of the PO-p was determined using an MALDI-TOF MS of AB SCIEX 5800. The samples were dissolved in methanol and mixed with the matrix, CHCA (a-cyano-4-hydroxynammic acid) before it was deposited on the plate for measurement.

\subsection{Hydroxyl Value (OH Value)}

The $\mathrm{OH}$ value of the polyols was determined using AOCS Official Method Cd 13-60 [34]. The sample preparation was done based on the method described in the standard.

\subsection{RESULTS AND DISCUSSION}

\subsection{Fourier Transform Infra-Red Spectroscopy (FTIR)}

FTIR spectra of all samples are shown in Figure 2. Based on the FTIR spectra, epoxy group of EPO appears at the waveband of $824-830 \mathrm{~cm}^{-1}$. At 6 hours of reaction (PRT06), the peak intensity of the epoxy has been reduced and the change in intensity marks that ring opening has occured. However, it cannot be assumed here that ring opening was complete after 24 hours due to the structure of the palm oil itself. According to Deffense (1985), palm oil consists of $48 \%$ disaturated triglyceride and $44 \%$ monosaturated triglyceride as shown in Figure 3. Hence, the distribution of the unsaturated site of the epoxy groups is not fixed depending on the location of the unsaturated double bond in the molecule. If the epoxy site is located in the middle of fatty acid, it will be difficult for the IPA to reach the site due to steric hindrance. Thus, it can be expected here that if the molar ratio of EPO to IPA was increased, the ring opening reaction could be completed within 24hours. The disappearance of -C-O-C stretching of epoxy [36] at $1160 \mathrm{~cm}^{-1}$ also supported the fact that the ring opening reaction has occurred. The peak intensity of the epoxy group is small as can be seen in the spectra because the Oxirane Oxygen Content (OOC) of the EPO only around $2.7-2.9 \%$.

As the reaction took place, the formation of $-\mathrm{OH}$ band at $3500 \mathrm{~cm}^{-1}$ should be clearly seen in the spectra [37]. However, in this study, there was a strong peak at around $3300 \mathrm{~cm}^{-1}$ which were due to the intermolecular hydrogen bonding of the $-\mathrm{OH}$ among the molecule. The existence of this peak in the spectra proved that the $-\mathrm{OH}$ functional group has been introduced in the palm oil molecular structure and the presence of $-\mathrm{OH}$ functionality in the molecule of isopropanolamine itself has increased the intensity of the $-\mathrm{OH}$ groups that govern the hydrogen bonding in the polyols. 


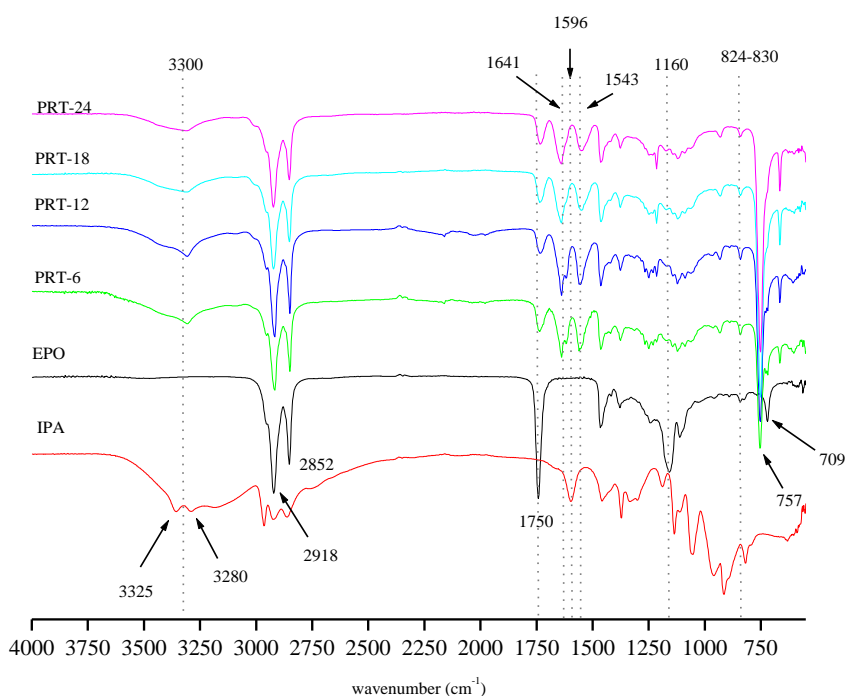

Figure 2 FTIR Spectra of polyols samples at different reaction time

Ring opening acid catalyzed with IPA is a type of nucleophilic addition reaction [38]. IPA contains both $-\mathrm{OH}$ and $-\mathrm{NH}$ groups that have the potential to be a nucleophile. However, based on the strength of the nucleophile, $-\mathrm{NH}$ group was thought, to attack the electrophilic site of the epoxide and carbonyl group of the ester linkage in the EPO molecule (Scheme 1). At the epoxy site, the nucleophile would directly attack the electropositive site of the epoxy and directly open the ring of the epoxy to produce secondary alcohol and amine moieties. Meanwhile, the attack of nucleophile at the carbonyl of the ester led to the breakage of the ester linkage and the formation of the amide. The amide formation was supported by the existence of $-\mathrm{C}=\mathrm{O}$ and $-\mathrm{NH}$ stretching of amide clearly visible in the range of $1641 \mathrm{~cm}^{-1}$ and $1543 \mathrm{~cm}^{-1}$ respectively. The disappearance of broad $-\mathrm{NH}_{2}$ scissor band of IPA at $1596 \mathrm{~cm}^{-1}$ also proved that the IPA has been successfully reacted with the active site in the EPO molecule (carbonyl carbon and epoxy carbon). The shift of methylene band of EPO from $709 \mathrm{~cm}^{-1}$ to 757 $\mathrm{cm}^{-1}$ has indicated the disintegration of methylene bulky groups in EPO into the individual fatty acid chain after the breaking of ester linkages for amidation to take place. Even though the nucleophile prefers to attack carbonyl site of the ester over the epoxy carbon [28], based on the formation of both amide groups and hydroxyl groups, it seems that the amidation and the opening of epoxy groups occur simultaneously during the reaction [28]. Hence, it was expected that there are four possible products obtained in this reaction as shown in Figure 7. Since the use of IPA broke all the ester linkages of the triglyceride, the glycerol moiety would also be obtained in the product of the reaction.
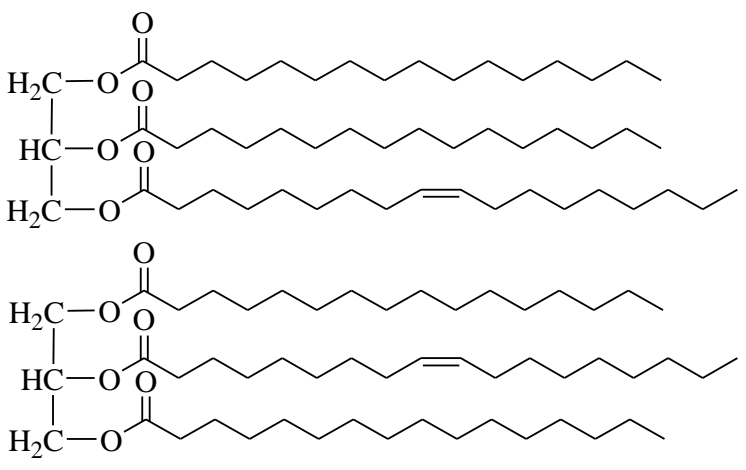

Disaturated triglyceride

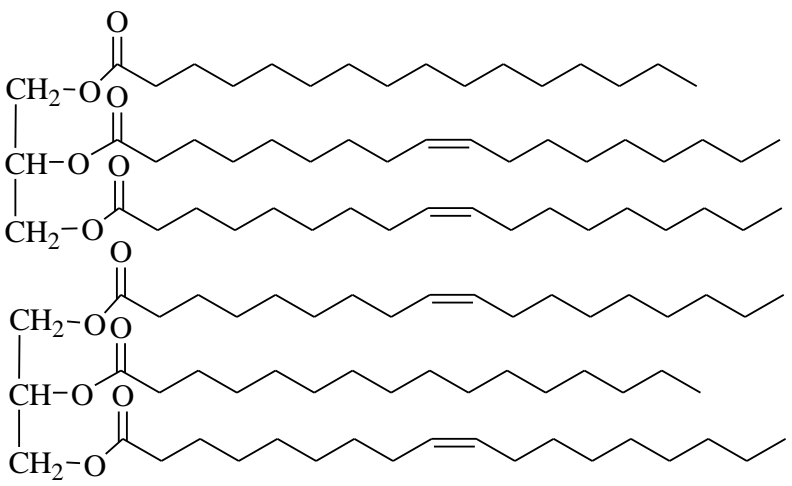

Monosaturated triglyceride

Figure 3 The distribution of unsaturated site in triglyceride of palm oil

\section{2 ${ }^{1} \mathrm{H}$ Nuclear Magnetic Resonance Spectroscopy ('H NMR)}

'H NMR was used to elucidate the molecular structure of the polyols. Figure 4 shows the ${ }^{1} H$ NMR spectra of the polyols obtained at different reaction time compared with the spectra of EPO. The ${ }^{1} \mathrm{H}$ of epoxy ring appeared at $2.89 \mathrm{ppm}$ (signal 6 of Figure 5 ) and this peak was detected in all the polyols obtained but with less intense (Figure 4). After 6h reaction, the epoxy ring (signal 8 of Figure 6) still detected with less intensity indicated the unreacted epoxy remaining in the product. This also indicates that the NMR analysis is more sensitive in detection of a structure compared to FTIR analysis since NMR spectroscopy is able to detect very fine structural components [39]. The reduction signal of the epoxy proton and the existence of signal $9(3.11 \mathrm{ppm})$ and signal 10 (3.99-3.44 ppm) which represent the $\left(\mathrm{CH}_{-}-\right.$ $\mathrm{NH})$ and $(\mathrm{CH}-\mathrm{OH})$ respectively in the polyol supports that the ring opening of the EPO can be done with IPA. Since the main purpose of this study was to investigate the availability of IPA as ring opening reagent to EPO, the molar ratio was set to 1:3 (EPO: IPA) because it was expected that there are three epoxy group per molecule of EPO. Meanwhile, the disappearance of the signal 7 and signal 8 of EPO which corresponded to the proton of $s n-1,3$ and sn-2 respectively showed that the triglyceride molecule has broken into its individual fatty acid chain and this 
supported the fact that IPA nucleophile breaks all the ester linkages of the triglyceride. In addition, the presence of glycerol proton (signal 12) in the polyols also marks the findings that the breaking of ester linkages is more favourable in this reaction. Signal 1 in Figure 5 correspondence to the terminal $\left(-\mathrm{CH}_{3}\right)$ proton of fatty acid whereas the signal 2 in Figure 6 correspondence to the terminal $\left(-\mathrm{CH}_{3}\right)$ proton of IPA. These two signals together with signal 15(-NH- amide) of Figure 6 also support the findings that IPA has the ability to become as ring opening reagent for EPO.

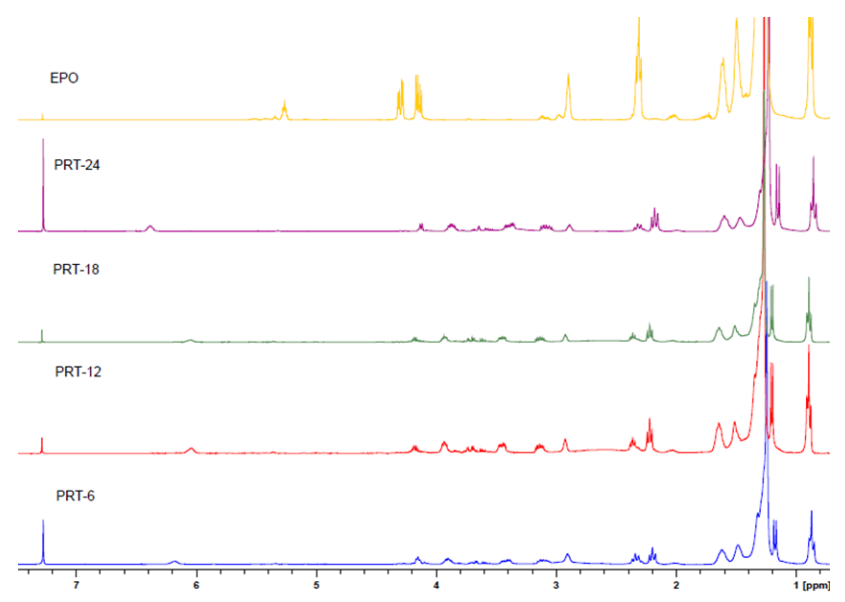

Figure 4 IH NMR spectra of poylols at different reaction time

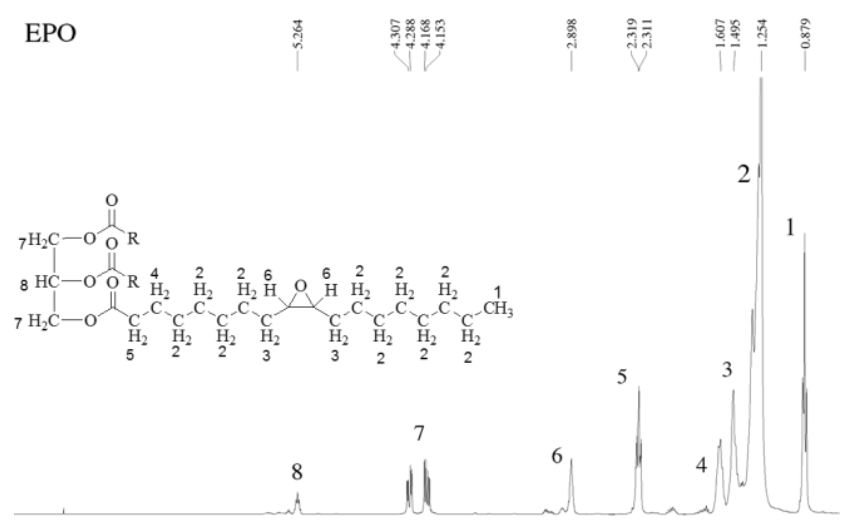

Figure 5 H NMR spectra of EPO

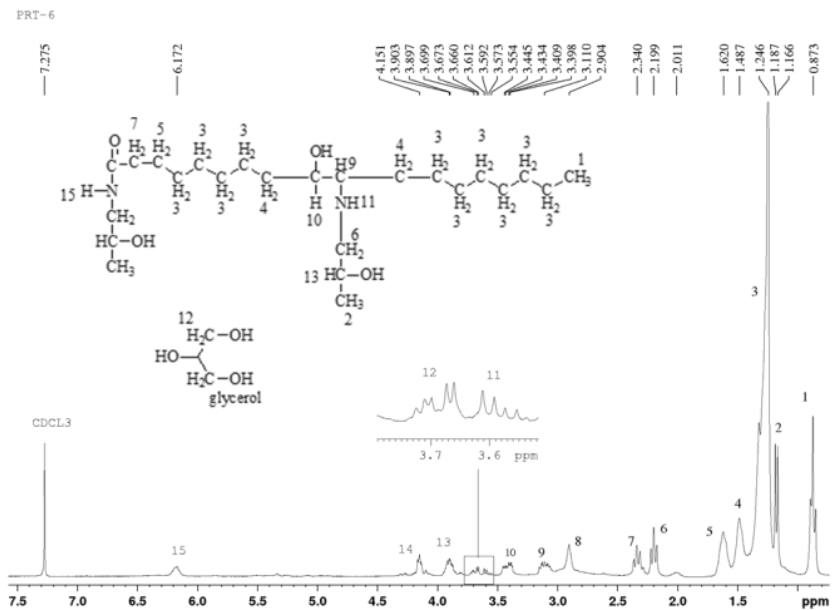

Figure $6{ }^{1} \mathrm{H}$ NMR spectra of EPO ring opened with isopropanolamine at $6 \mathrm{~h}$ reaction time

\subsection{MALDI-TOF Mass Spectrometry}

The molecular weight of the polyols was determined by comparing the spectra of the polyols with the spectra of matrix used in the analysis. Based on the analysis, most of the fragmented ions are in the sodiated form $[\mathrm{M}+\mathrm{Na}]^{+}$and the polyols obtained in this study have a molecular weight ranging between 300 - 400 Da which is nearly the molecular weight of the proposed polyols in Figure 7. The reduction of this molecular weight after the reaction (MW of $\mathrm{EPO}=848.75 \mathrm{Da})$ showed that the triglyceride molecule has broken into its individual fatty acid chains and as expected from Figure 7, the final product mainly of polyol B since it was identical to the molecular weight obtained from this MALDI-TOF analysis.

Table 1 Physical characteristic of palm oil polyols

\begin{tabular}{ccclc}
\hline Polyols & $\begin{array}{l}\text { Reaction } \\
\text { Time (h) }\end{array}$ & $\begin{array}{l}\text { Molecular } \\
\text { Weight } \\
{[\mathbf{M + N a}]^{+}(\mathbf{D a})}\end{array}$ & $\begin{array}{l}\text { OH } \\
\text { Value } \\
(\mathbf{m g} \\
\mathbf{K O H} / \mathbf{g})\end{array}$ & $\begin{array}{l}\text { Functionality } \\
\left(\boldsymbol{f}_{\mathbf{x}}\right)\end{array}$ \\
\hline EPO & - & 848.75 & - & - \\
P06 & 6 & 445 & 253.91 & 2 \\
P12 & 12 & 445 & 253.28 & 2 \\
P18 & 18 & 443 & 251.04 & 2 \\
P24 & 24 & 431 & 240.91 & 2 \\
\hline
\end{tabular}

\section{$3.4 \mathrm{OH}$ Value}

The $\mathrm{OH}$ value of the obtained polyols is shown in Table 1. The $\mathrm{OH}$ value is defined as the number of milligrams of potassium hydroxide $(\mathrm{KOH})$ equivalent to the hydroxyl content of $1.0 \mathrm{~g}$ of polyol. From this $\mathrm{OH}$ value, the quantitative value of the amount of hydroxyl groups available for the reaction with isocyanate can be determined [40]. $\mathrm{OH}$ value also gives information on the functionality $\left(f_{x}\right)$ of the 
synthesized polyol provided that the molecular weight, $\mathrm{MW}$ is known.

$$
\begin{aligned}
& \text { Functionality, } f_{x}=\frac{\text { molecular weight }}{\text { equivalance weight }} \\
& \begin{array}{lll}
\text { While-; } & \text { Equation } 1 \\
\text { Equivalent weight }=\frac{(56)(1000)}{\mathrm{OH} \text { Value }} & \ldots . . .
\end{array} \quad \text { Equation } 2
\end{aligned}
$$

Even though isopropanolamine itself contains $-\mathrm{OH}$ groups, it did not affect the functionality of the polyols obtained. It was expected that higher functionality of polyols $(\geq 4)$ would be obtained when isopropanolamine reacted with monosaturated triglyceride because when isopropanolamine opened the two epoxy ring, it is possible to produce polyol with functionality equals to four. Secondary hydroxyl group has been produced in this study. Based on the $\mathrm{OH}$ value, there might be the possibility that the $\mathrm{OH}$ group only contributed to the intermolecular $\mathrm{H}$-bonding instead of active $\mathrm{OH}$ that would react with isocyanate functionality in the polyurethane synthesis later because some of the $\mathrm{OH}$ group are located in the middle of the fatty acid and this might hindered them from any chemical reactions. In addition, the functionality was found to be only 2 and this indicated that there were inactive $-\mathrm{OH}$ groups in the polyols. However, this low functionality of the palm oil polyols is desirable to formulate flexible polyurethane for coating application [40]. The obtained $\mathrm{OH}$ value in this study was found to be higher than palm oil polyols obtained using transesterification reaction by [22] and ring opening reaction with phthalic acid by [37]. It was also observed in this study that by prolonging the reaction time, the $\mathrm{OH}$ value was found to be decreased.
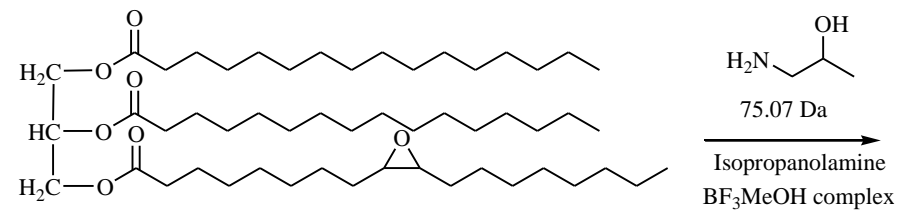

848.75 Da

Epoxidized Palm Oil
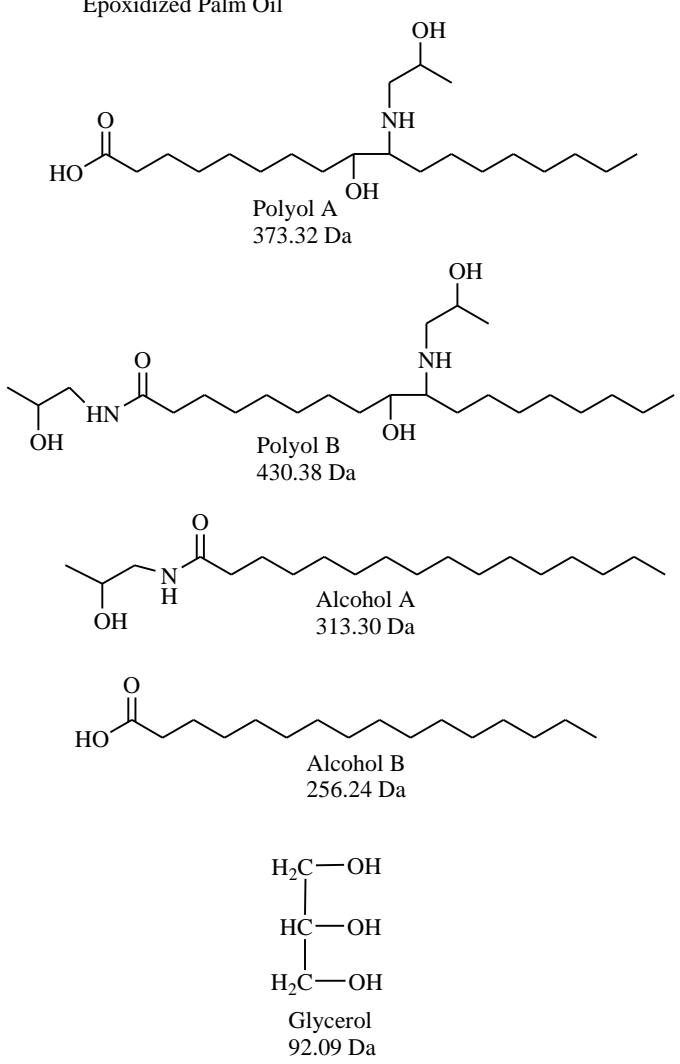

Figure 7 Reaction route of the ring opening reaction of EPO with isopropanolamine [41]

\subsection{CONCLUSION}

This study has proven that a bio-based polyol with amine functionalized have been successfully synthesized. The reaction time was found to have no significant effect on the characteristic of the polyols. Upon reacting with isocyanate counterparts for polyurethane synthesis, it is expected that the presence of amine functionality in the polyols will improve certain properties like antioxidant characteristic. In addition, the presence of hydrogen bonding will influence the hard and soft segment of the corresponding polyurethane synthesized from these polyols. 


\section{Acknowledgement}

Authors would like to thank Ministry of Education Malaysia (MOE) and UTM for funding this research under VOTE Number R.J130000.7844.4L1 41 (ERGS).

\section{References}

[1] M. Alam, D. Akram, E. Sharmin, F. Zafar, and S. Ahmad. 2014. Vegetable Oil Based Eco-friendly Coating Materials: A Review Article. Arab. J. Chem. 7(4): 469-479.

[2] M. Desroches, M. Escouvois, R. Auvergne, S. Caillol, and B. Boutevin. 2012. From Vegetable Oils to Polyurethanes: Synthetic Routes to Polyols and Main Industrial Products. Polymer Reviews. 52(1): 38-79. Taylor \& Francis.

[3] G. Lligadas, J. C. Ronda, M. Galià, and V. Cádiz. 2010. Plant Oils as Platform Chemicals for Polyurethane Synthesis: Current State-of-the-Art. Biomacromolecules. 11 (11): 2825-2835.

[4] M. Jalilian, H. Yeganeh, and M. N. Haghighi. 2008. Synthesis and Properties of Polyurethane Networks Derived from New Soybean Oil-based Polyol and a Bulky Blocked Polyisocyanate. Polym. Int. 57(12): 1385-1394.

[5] E. A. Ismail, A. M. Motawie, and E. M. Sadek. 2011. Synthesis and Characterization of Polyurethane Coatings based on Soybean Oil-polyester Polyols. Egypt. J. Pet. 20(2): 1-8.

[6] H. Bakhshi, H. Yeganeh, S. Mehdipour-Ataei, M. A. Shokrgozar, A. Yari, and S. N. Saeedi-Eslami. 2013. Synthesis and Characterization of Antibacterial Polyurethane Coatings from Quaternary Ammonium Salts Functionalized Soybean Oil Based Polyols. Mater. Sci. Eng. C. 33(1): 153164.

[7] X. Kong, G. Liu, and J. M. Curtis. 2011. Characterization of Canola Oil Based Polyurethane Wood Adhesives. Int. J. Adhes. Adhes. 31 (6): 559-564.

[8] A. S. A. Hazmi, M. M. Aung, L. C. Abdullah, M. Z. Salleh, and M. H. Mahmood. 2013. Producing Jatropha Oil-based Polyol Via Epoxidation and Ring Opening. Ind. Crops Prod. 50: 563-567.

[9] S. N. Khot et al. 2001. Development and Application of Triglyceride-based Polymers and Composites. J. Appl. Polym. Sci. 82: 703-723.

[10] M. a R. Meier, J. O. Metzger, and U. S. Schubert. 2007. Plant Oil Renewable Resources as Green Alternatives in Polymer Science. Chem. Soc. Rev. 36(11): 1788-1802.

[11] A. Dotan. 2014. Handbook of Thermoset Plastics. Elsevier.

[12] P. D. Meshram, R. G. Puri, A. L. Patil, and V. V. Gite. 2013. Synthesis and Characterization of Modified Cottonseed Oil based Polyesteramide for Coating Applications. Prog. Org. Coatings. 76(9): 1144-1150.

[13] R. D. Kulkarni, P. S. Deshpande, S. U. Mahajan, and P. P. Mahulikar. 2013. Epoxidation of Mustard Oil and Ring Opening with 2-ethylhexanol for Biolubricants with Enhanced Thermo-oxidative and Cold Flow Characteristics. Ind. Crops Prod. 49: 586-592.

[14] A. Guo, D. Demydov, W. Zhang, and Z. S. Petrovic. 2002. Polyols and Polyurethanes from Hydroformylation of Soybean Oil. J. Polym. Environ. 10: 49-52.

[15] Z. S. Petrović, W. Zhang, and I. Javni. 2005. Structure and Properties of Polyurethanes Prepared from Triglyceride Polyols by Ozonolysis. Biomacromolecules. 6(2): 713-719.

[16] V. V. Goud, S. Dinda, A. V. Patwardhan, and N. C. Pradhan. 2010. Epoxidation of Jatropha (Jatropha curcas) oil by Peroxyacids. Asia-Pacific J. Chem. Eng. 5(2): 346354.

[17] FOASTAT. 2014. Food and Agriculture Organization of The United Nations.

[18] M. Z. Arniza et al. 2015. Synthesis of Transesterified Palm Olein-Based Polyol and Rigid Polyurethanes from this Polyol. J. Am. Oil Chem. Soc. 92(2): 243-255.

[19] L. H. Gan, S. H. Goh, and K. S. Ooi. 1992. Kinetic Studies of
Epoxidation and Oxirane Cleavage of Palm Olein Methyl Esters. J. Am. Oil Chem. Soc. 69(4): 347-351.

[20] C. S. Lee, T. L. Ooi, C. H. Chuah, and S. Ahmad. 2007. Rigid Polyurethane Foam Production from Palm Oil-Based Epoxidized Diethanolamides. J. Am. Oil Chem. Soc. 84(12): 1161-1167.

[21] K. H. Badri, S. H. Ahmad, and S. Zakaria. 2001. Production of a High-functionality RBD Palm Kernel Oil-based Polyester Polyol. J. Appl. Polym. Sci. 81 (2): 384-389.

[22] D. Lumcharoen and O. Saravari. 2014. Preparation and Characterization of Flexible Polyurethane Foams from Palm Oil-Based Polyol. Adv. Mater. Res. 911: 352-356.

[23] J. G. Smith. 2006. Oxidation and Reduction. Organic Chemistry. 419.

[24] D. Derawi and J. Salimon. 2010. Optimization on Epoxidation of Palm Olein by Using Performic Acid. EJournal Chem. 7(4): 1440-1448.

[25] S. S. Narine, J. Yue, and X. Kong. 2007. Production of Polyols from Canola Oil and Their Chemical Identification and Physical Properties. JAOCS, J. Am. Oil Chem. Soc. 84: 173-179.

[26] S. H. Feairheller, R. G. Bistline Jr., A. Bilyk, R. L. Dudley, M. F. Kozempel, and M. J. Haas. 1994. A Novel Technique for the Preparation of Secondary Fatty Amides. J. Am. Oil Chem. Soc. 71 (8): 863-866.

[27] T. F. Garrison, M. R. Kessler, and R. C. Larock. 2014. Effects of Unsaturation and Different Ring-opening Methods on the Properties of Vegetable Oil-based Polyurethane Coatings. Polymer (Guildf). 55(4): 1004-1011.

[28] S. Miao, S. Zhang, Z. Su, and P. Wang. 2013. Synthesis of Bio-based Polyurethanes from Epoxidized Soybean Oil and Isopropanolamine. J. Appl. Polym. Sci. 127: 1929-1936.

[29] B. J. K. Ahn, S. Kraft, and X. S. Sun. 2012. Solvent-free Acidcatalyzed Ring-opening of Epoxidized Oleochemicals Using Stearates/Stearic Acid, and Its Applications. J. Agric. Food Chem. 60: 2179-2189.

[30] H. Dai, L. Yang, B. Lin, C. Wang, and G. Shi. 2009. Synthesis and Characterization of the Different Soy-based Polyols by Ring Opening of Epoxidized Soybean Oil with Methanol 1,2-Ethanediol and 1,2-Propanediol. J. Am. Oil Chem. Soc. 86(3): 261-267.

[31] Z. Lozada, G. J. Suppes, Y. C. Tu, and F. H. Hsieh. 2009. Soybased Polyols from Oxirane Ring Opening by Alcoholysis Reaction. J. Appl. Polym. Sci. 113(4): 2552-2560.

[32] W. R. Morrison and L. M. Smith. 1964. Preparation of Fatty Acid Methyl Esters and Dimethylacetals from Lipids with Boron Fluoride-methanol. J. Lipid Res. 5(4): 600-608.

[33] Z. S. Petrović. 2010. Polymers From Biological Oils. Contemp. Mater. I(1): 39-50.

[34] AOCS. [Online]. Available: http://www.aocs.org/attainlab-services/methods/methods/methoddetail?productld=111525. [Accessed: 15-Aug-2016].

[35] E. Deffense. 1985. Fractionation of Palm Oil. J. Am. Oil Chem. Soc. 62(2): 376-385.

[36] G. M. Lampman, D. L. Pavia, G. S. Kriz, and J. R. Vyvyan. 2010. Spectroscopy. 4th edition. Brooks/Cole.

[37] K. P. Ang, C. S. Lee, S. F. Cheng, and C. H. Chuah. 2014. Synthesis of Palm Oil-based Polyester Polyol for Polyurethane Adhesive Production. J. Appl. Polym. Sci. 131 (6): 39967 (1 Of 8).

[38] J. C. Ronda, G. Lligadas, M. Galià, and V. Cádiz. 2011. Vegetable Oils as Platform Chemicals for Polymer Synthesis. Eur. J. Lipid Sci. Technol. 113(1): 46-58.

[39] L. G. Butler. 2003. An Introduction to Solution, Solid-State, and Imaging NMR Spectroscopy. Handbook of Spectroscopy. Wiley-VCH Verlag GmbH \& Co. KGaA. 177208.

[40] Mihail Ionescue. 2005. Chemistry and Technology of Polyols for Polyurethanes. Shropshire, UK: Rapra Technology Limited.

[41] A. Campanella and M. A. Baltanás. 2005. Degradation of the Oxirane Ring of Epoxidized Vegetable Oils in Liquidliquid Systems: II. Reactivity with Solvated Acetic and Peracetic Acids. Lat. Am. Appl. Res. 35(3): 211-216. 